\title{
Incidence, pattern and factors associated with home accidents among the elderly in Wattala Medical Officer of Health area, Sri Lanka
}

\author{
Rasika Jayasekera $^{1^{*}}$ \& Chrishantha Abeysena ${ }^{2}$ \\ ${ }^{1}$ Divisional Hospital Pamunugama, Ministry of Health; ${ }^{2}$ Department of Public Health, Faculty of Medicine, University \\ of Kelaniya, Sri Lanka \\ "Correspondence: rasikanilanjayasekera@gmail.com
}

DOI: https://doi.org/10.4038/jccpsl.v24i4.8157

Received on: 16 May 2018

Accepted on: 03 October 2018

\begin{abstract}
Background: Good health is essential for older people to remain independent and to play a significant role in the family as well as in the community. Home accident is one that causes significant morbidity and mortality in the elderly population and a burden to the family and country.
\end{abstract}

Objective: To determine the incidence and factors associated with home accidents among elders aged 60 years and above in Wattala Medical Officer of Health $(\mathrm{MOH})$ area

Methods: This was a cross-sectional study carried out among 884 elderly persons selected using cluster sampling method. An interviewer-administered questionnaire was used to collect data. Multiple logistic regression was applied to calculate adjusted odds ratio and $95 \%$ CI.

Results: The incidence of home accidents among the elderly during past one month was $10.9 \%$ (95\% CI=8.7, 13.1). It was $16.4 \%(95 \% \mathrm{CI}=4.8,27.9)$ among those aged 75 years and above and $8.9 \%(95 \% \mathrm{CI}=6.5,11.3)$ between 60 to 74 years. The sex-specific incidence of home accidents was $11.2 \%(95 \% \mathrm{CI}=7.5,14.8)$ among females and $10.4 \%$ (95\% CI=5.1, 15.6) among males.

Of the 96 home accidents, most were due to falls at the same level ( $\mathrm{n}=40,41.7 \%)$; occurred between 8.00 am to 12 noon $(\mathrm{n}=27,28.1 \%)$ and between $4.00 \mathrm{pm}$ to $8.00 \mathrm{pm}(\mathrm{n}=26,27.1 \%)$; and took place in bed room $(\mathrm{n}=35,36.5 \%)$. Among the victims, $80(83.3 \%)$ had an injury most commonly on the head and neck area $(n=33,41.7 \%)$. The majority received treatment from general practice $(89.6 \%)$ and out-patient department of private hospitals $(52.4 \%)$.

Presence of hypertension $(\mathrm{OR}=1.96 ; 95 \% \mathrm{CI}=1.3,3.0)$, arthritis $(\mathrm{OR}=2.4 ; 95 \% \mathrm{CI}=1.5,3.8)$ and difficulty in the mobility of upper part of the body $(\mathrm{OR}=2.2 ; 95 \% \mathrm{CI}=1.3,3.9)$ were significant factors associated with the occurrence of home accidents after adjusting for confounders.

Conclusions: Awareness programs should be conducted on home accidents for caregivers especially caring for elders with physical disabilities.

Key words: factors, elderly, home accidents, incidence, pattern 


\section{Introduction}

The current world exists with an ageing population. The growth rate of the older population is higher than that of the total population (1). This situation is true of Sri Lanka as well. In Sri Lanka, it is estimated that the elderly population $(60+$ years $)$ will rise from 1.6 million in 2006 to 3.6 million in 2021 (2). Good health is essential for older people to remain independent and to play a part in the family as well as in the community. Home accident is one that which causes significant morbidity and mortality in the elderly population and a burden to the family and country.

The World Health Organization defines accident as "an event independent of human will caused by an outside force, acting rapidly, which results in bodily or mental injury" (3). Home accidents cause significant morbidity and mortality in the elderly population. Types of home accidents experienced by the elderly are varied and include falls, burns, scalds, poisoning, cut/pierce injuries, suffocation and drowning. The most common accidents among the elderly are falls and burns (4).

As the number of older people in the community increases, the management of home accidents will make increasing demands on healthcare services. It increases the healthcare expenditure while the negative effects on the lifestyle of persons affected demonstrate that home accidents among the elderly is fast becoming a public health priority (5). When people get older, their body reserves get reduced due to impairment of elasticity in tissues and due to disuse atrophy. This affects the body's ability to compensate quickly enough to avoid impending accidents.

A few studies have been done with the Sri Lankan population to measure home accidents in the elderly. Kumarasiri and colleagues reported a prevalence of $4.8 \%$ for home accidents in the elderly in a rural area in Sri Lanka (6). A Malaysian study reported that 5.8\% of the elderly aged 60 years and above had experienced some form of home injury within the previous year (7). The studies done in other countries reveal higher prevalence of home accidents among the elderly (5, 8). A community-based study on home accidents has not been done among elders earlier in an urban area. Therefore, the objective of this study was to determine the incidence, pattern and associations of selected factors with the occurrence of home accidents among those aged 60 years and above in the medical officer of health $(\mathrm{MOH})$ area, Wattala.

\section{Methods}

A descriptive, cross-sectional study was carried out in Wattala MOH area, which is a newly developed urban area where much development has taken place including the health sector. The study population consisted of elderly people aged 60 years and above residing in Wattala $\mathrm{MOH}$ area during last one month. The exclusion criteria were semi-conscious or bedridden elderly persons, persons diagnosed to have Alzheimer's disease and those who cannot understand Sinhala or English languages.

The sample size was calculated by considering the estimated prevalence of home accidents as $10 \%$, desired level of precision as $2.5 \%, 95 \%$ desired level of confidence and design effect as 1.5. Accordingly, the required sample size was 829. A further adjustment to the sample size was made considering a nonresponse rate of $10 \%$, making the final sample size 912. The total population of $\mathrm{MOH}$ area Wattala is around 157,670 , of which the elderly population is around 14,000 . This $\mathrm{MOH}$ area has 34 public health midwife (PHM) areas, of which 19 were selected as clusters by simple random sampling using lottery method without replacement. Two roads were selected randomly from each of these PHM areas while the index point was the first household identified along the road on the left side. The direction proceeded when collecting data was to the left of the front door of the index house. When there was more than one elderly person in a household, one person was selected randomly. If an elderly person was not found in a household, next house on the left side was selected.

A pre-tested, interviewer-administered questionnaire prepared in both Sinhala and English languages was used for data collection. The questions were worded in a simple way which enabled them to understand easily. The questionnaire consisted of sociodemographic and economic factors, health related factors of elderly people and details of the home accident. Two pre-intern doctors were recruited as data collectors. They were given four three-hour sessions of training for a period of two days including a practical session. The data collection was done on an everyday basis including Saturday, Sunday and public holidays. Data collection was done from 9.00 am to $5.00 \mathrm{pm}$. Two data collectors separately collected data based on the directions given by principal investigator. From each PHM area, 48 households with elderly had to be visited to obtain the sample size of 
912 in 19 PHM areas. The average duration of the questionnaire was 15 minutes. At the end of the day, principal investigator collected the questionnaires and checked for missing data. A pilot study was conducted in Mahara $\mathrm{MOH}$ area to identify the changes to be done related to data collection, so as to increase the cooperation of the study participants and the validity of the study.

'Less educated' was defined as those having an education below grade eight. 'Ability to do daily activities' included eating, dressing, toileting, bathing, transferring from bed or chair and combing or shaving. 'Mobility of the body' was defined as the ability of a person to move the body. When the movements were few or none, it was taken as 'impaired movement'. 'Home accident' was defined as an accident that took place in and around the house including the dwelling unit itself, garden, yard, garage, and all that is personal to the household.

Data were analysed by using Statistical Package for Social Sciences (SPSS) version 16.0. Initially, frequency distributions were analysed for each variable. Age- and sex-specific incidence of home accidents among the study population including $95 \%$ confidence interval (CI) was calculated. The associations of selected factors with the occurrence of home accidents were assessed by applying chi-squared test. Multiple logistic regression was applied to control the confounding factors.

A brief introduction of the research was given to the study participants, and informed written consent was obtained. If an elderly was found to have any disability that required medical attention, a referral letter was given addressed to the closest health institution. Anonymity of the patients was maintained by not recording the name and address of the participants. The data obtained for this study were treated with confidentiality and used only for research purpose. Permission to carry out the study was obtained by the Deputy Provincial Director of Health Services of Gampaha District, Divisional Secretariat of Wattala and $\mathrm{MOH}$ of Wattala.

\section{Results}

A total of 28 elderly persons refused to participate. Therefore, the final study sample was 884 , giving a non-response rate of $3.1 \%$. The majority consisted of females $(n=537,60.7 \%)$ and were in the age group of
60-74 years. The number aged 85 years and above was only $58(6.6 \%)$. A majority of the study population was Sinhalese $(\mathrm{n}=667,75.5 \%)$ followed by Tamils $(\mathrm{n}=170,19.2 \%)$ and Muslims $(\mathrm{n}=45,5.1 \%)$. The proportion of Catholics was $49.3 \%(\mathrm{n}=436)$ followed by Buddhists $(\mathrm{n}=255,28.8 \%)$, Hindus $(\mathrm{n}=148,16.7 \%)$ and Islamic persons $(\mathrm{n}=45,5.2 \%)$.

Most of the study participants had been educated only up to grade eight $(\mathrm{n}=265,30.0 \%)$ while $25 \%$ $(n=221)$ had studied up to GCE Ordinary Level. Only $2.3 \%(\mathrm{n}=20)$ had received higher education in contrast to $39(4.4 \%)$ who had never attended school. The proportion of currently married persons was $47.9 \%$ $(n=424)$ while $47.6 \%(n=421)$ were widowed. There were 861 (97.4\%) persons living with their spouse, children, grandchildren or with a relation in the same house, while the proportion living alone during daytime was $17.0 \%(\mathrm{n}=150)$. Among them, $669(75.7 \%)$ were not employed while 135 (15.3\%) were employed in the private sector and $80(9.0 \%)$ in self-employment.

The incidence of home accidents among the elderly was $10.9 \%(95 \% \mathrm{CI}=8.74,13.06)(\mathrm{n}=96)$ during the past one month. Among the age groups, the incidence was $8.89 \%(95 \% \mathrm{CI}=6.46,11.32)(\mathrm{n}=58)$ and $16.38 \%$ $(95 \% \mathrm{CI}=4.82,27.94)(\mathrm{n}=38)$ among the $60-74$ years and 75 years and above age groups, respectively. Home accidents were reported in almost equal proportions by females $(11.0 \% ; 95 \% \mathrm{CI}=7.54,14.8)$ and males (10.38\%; 95\% CI=5.13, 15.63). Only one elderly person had reported two episodes of accidents during past one month.

Out of all home accidents, most had been due to falls at the same level $(\mathrm{n}=40,41.7 \%)$ while $16(16.6 \%)$ had cuts and 15 (15.6\%) had been knocked against objects. Nine persons had fallen from a height; six had a foreign body in eye or an orifice; and four reported burn injuries. Home accidents have occurred in the majority in the morning between 4.00 am to 12.00 noon $(\mathrm{n}=52,54.1 \%)$ and in the evening between 4.00 pm to $8.00 \mathrm{pm}(\mathrm{n}=39,40.6 \%)$. No accident has been reported between 12.00 midnight to $4.00 \mathrm{am}$. Most of the home accidents have occurred in the bed room $(\mathrm{n}=35,36.5 \%)$ followed by the living or dining rooms $(\mathrm{n}=19,19.8 \%)$. Only $16.7 \%(\mathrm{n}=16)$ have occurred in the garden and $10.4 \%(\mathrm{n}=10)$ both in the bathroom and kitchen. The proportion of home accident-victims who had met with an injury was $83.3 \%(n=80)$. Among them, $33(41.2 \%)$ had injuries in head and neck area followed by injuries in upper limb $(n=30,37.5 \%)$, lower 
limb $(n=15,18.8 \%)$ and trunk $(n=2,2.4 \%)$. Out of the 80 injured persons, $43(53.8 \%)$ had lacerations, $23.7 \%(n=19)$ had contusions and $5 \%(n=4)$ had burn injuries. Only two had encountered a fracture.

Out of all the victims of home accidents, 86 $(89.6 \%)$ have received treatment after the home accident. A majority $(n=44,52.4 \%)$ had gone to a general practitioner or to the out-patient department (OPD) of a private hospital, of whom $15(17.4 \%)$ had inward treatment; $14(16.3 \%)$ had gone to the OPD in government hospitals; and $10(11.6 \%)$ had home remedies after the accident.

Of the demographic and socio-economic factors, age above 75 years, Muslim ethnic group and those having own income were significantly associated with a higher occurrence of home accidents $(p<0.05)$ (Table 1). Difficulty in performing the activities of daily living such as eating, dressing, toileting, bathing, transferring from bed or chair, and combing or shaving showed significant associations with the occurrence of home accidents (Table 2). Of the co-morbidities, presence of diabetes mellitus, hypertension, arthritis and hypercholesterolemia had significant associations with the occurrence of home accidents $(\mathrm{p}<0.05)$. Also, self-reported visual or hearing impairment and difficulty in the mobility of upper part and lower part of the body showed significant associations (Table 3). Of these, presence of hypertension, arthritis, difficulty in the mobility of upper part of the body were the factors associated with the occurrence of home accidents after controlling for confounding effects of other variables (Table 4).

Table 1. Socio-demographic factors and the occurrence of home accidents in the sample

\begin{tabular}{|c|c|c|c|}
\hline \multirow[t]{2}{*}{ Socio-demographic factors } & \multicolumn{2}{|c|}{ Home accidents, No. (\%) } & \multirow[b]{2}{*}{ OR $(95 \% \mathrm{CI})$} \\
\hline & Yes & No & \\
\hline \multicolumn{4}{|l|}{$\overline{\text { Age }}$} \\
\hline $60-74$ years & $58(8.9)$ & $594(91.1)$ & $0.5(0.3-0.7)$ \\
\hline 75 and above years & $38(16.4)$ & $194(83.6)$ & 1.0 \\
\hline \multicolumn{4}{|l|}{ Sex } \\
\hline Male & $60(11.2)$ & $477(88.8)$ & $1.1(0.7-1.7)$ \\
\hline Female & $36(10.4)$ & $311(89.6)$ & 1.0 \\
\hline \multicolumn{4}{|l|}{ Ethnicity } \\
\hline Muslim & $10(22.2)$ & $35(77.8)$ & $2.5(1.2-5.2)$ \\
\hline Others & $86(10.25)$ & $753(89.8)$ & 1.0 \\
\hline \multicolumn{4}{|l|}{ Level of education } \\
\hline Less-educated & $36(12.6)$ & $250(87.4)$ & $1.3(0.8-2.0)$ \\
\hline Well-educated & $60(10.0)$ & $538(90.0)$ & 1.0 \\
\hline \multicolumn{4}{|l|}{ Current marital status } \\
\hline Married & $46(10.8)$ & $378(89.2)$ & $0.9(0.7-1.5)$ \\
\hline Unmarried/ widowed/ divorced & $50(10.9)$ & $410(89.1)$ & 1.0 \\
\hline \multicolumn{4}{|l|}{ Living status } \\
\hline Not living alone & $96(11.1)$ & $768(88.9)$ & $0.9(0.9-0.9)$ \\
\hline Living alone & $0(0.0)$ & $20(100.0)$ & 1.0 \\
\hline \multicolumn{4}{|l|}{ Status during day time } \\
\hline Not alone & $77(10.5)$ & $657(89.5)$ & $0.8(0.5-1.4)$ \\
\hline Alone & $19(12.7)$ & $131(87.3)$ & 1.0 \\
\hline \multicolumn{4}{|l|}{ Current employment } \\
\hline Not employed & $75(11.2)$ & $594(88.8)$ & $1.2(0.7-1.9)$ \\
\hline Employed & $21(9.8)$ & $194(90.2)$ & 1.0 \\
\hline \multicolumn{4}{|l|}{ Income status } \\
\hline Did not have own income & $30(18.9)$ & $129(81.1)$ & $2.3(1.5-3.7)$ \\
\hline Had own income & $66(9.1)$ & $659(90.9)$ & 1.0 \\
\hline
\end{tabular}


Table 2. Activities of daily living and the occurrence of home accidents

\begin{tabular}{|c|c|c|c|}
\hline \multirow[t]{2}{*}{ Activities of daily living } & \multicolumn{2}{|c|}{ Home accidents, No. (\%) } & \multirow[b]{2}{*}{ OR $(95 \% \mathrm{CI})$} \\
\hline & Yes & No & \\
\hline \multicolumn{4}{|l|}{ Eating } \\
\hline Difficult & $11(11.5)$ & $85(88.5)$ & $2.7(1.3-5.5)$ \\
\hline Can do & $85(10.2)$ & $752(89.8)$ & 1.0 \\
\hline \multicolumn{4}{|l|}{ Dressing } \\
\hline Difficult & $18(20.7)$ & $69(79.3)$ & $2.4(1.4-4.3)$ \\
\hline Can do & $78(9.8)$ & $719(90.2)$ & 1.0 \\
\hline \multicolumn{4}{|l|}{ Toileting } \\
\hline Difficult & $27(17.6)$ & $126(82.4)$ & $2.1(1.3-3.3)$ \\
\hline Can do & $69(9.4)$ & $662(90.6)$ & 1.0 \\
\hline \multicolumn{4}{|l|}{ Bathing } \\
\hline Difficult & $27(18.4)$ & $120(81.6)$ & $2.3(1.3-3.5)$ \\
\hline Can do & $69(9.4)$ & $668(90.6)$ & 1.0 \\
\hline \multicolumn{4}{|c|}{ Transferring from bed or chair } \\
\hline Difficult & $30(21.6)$ & $109(78.4)$ & $2.8(1.8-4.6)$ \\
\hline Can do & $66(8.9)$ & $679(91.1)$ & 1.0 \\
\hline \multicolumn{4}{|l|}{ Combing or shaving } \\
\hline Difficult & $14(21.5)$ & $51(78.5)$ & $2.5(1.3-4.7)$ \\
\hline Can do & $82(10.0)$ & $737(90.0)$ & 1.0 \\
\hline
\end{tabular}

Table 3. Health status of the elderly and the occurrence of home accidents

\begin{tabular}{|c|c|c|c|}
\hline \multirow[t]{2}{*}{ Health status of the elderly } & \multicolumn{2}{|c|}{ Home accidents, No. (\%) } & \multirow[b]{2}{*}{ OR $(95 \% \mathrm{CI})$} \\
\hline & Yes & No & \\
\hline \multicolumn{4}{|l|}{ Diabetes mellitus } \\
\hline Yes & $25(15.9)$ & $132(84.1)$ & $1.8(1.1-2.9)$ \\
\hline No & $71(9.8)$ & $656(90.2)$ & 1.0 \\
\hline \multicolumn{4}{|l|}{ Hypertension } \\
\hline Yes & $49(16.2)$ & $254(83.8)$ & $2.2(1.4-3.4)$ \\
\hline No & $47(8.1)$ & $534(91.9)$ & 1.0 \\
\hline \multicolumn{4}{|l|}{ Ischaemic heart disease } \\
\hline Yes & $12(10.9)$ & $98(89.1)$ & $1.0(0.5-1.9)$ \\
\hline No & $84(10.8)$ & $690(89.2)$ & 1.0 \\
\hline \multicolumn{4}{|l|}{ Diagnosed arthritis } \\
\hline Yes & $32(21.1)$ & $120(78.9)$ & $2.8(1.7-4.4)$ \\
\hline No & $64(8.7)$ & $668(91.3)$ & 1.0 \\
\hline \multicolumn{4}{|l|}{ Hypercholesterolemia } \\
\hline Yes & $28(15.3)$ & $155(84.7)$ & $1.7(1.1-2.7)$ \\
\hline No & $68(9.7)$ & $633(90.3)$ & 1.0 \\
\hline
\end{tabular}




\begin{tabular}{|c|c|c|c|}
\hline \multirow[t]{2}{*}{ Health status of the elderly } & \multicolumn{2}{|c|}{ Home accidents, No. (\%) } & \multirow[b]{2}{*}{ OR $(95 \% \mathrm{CI})$} \\
\hline & Yes & No & \\
\hline \multicolumn{4}{|l|}{ Cancer } \\
\hline Yes & $0(0.0)$ & $7(100.0)$ & $0.35(0.1-1.2)$ \\
\hline No & $96(10.9)$ & $781(89.1)$ & 1.0 \\
\hline \multicolumn{4}{|l|}{ Lung disease } \\
\hline Yes & $5(13.9)$ & $31(86.1)$ & $1.3(0.5-3.5)$ \\
\hline No & $91(10.7)$ & $757(89.3)$ & 1.0 \\
\hline \multicolumn{4}{|l|}{ Other diseases } \\
\hline Yes & $1(4.3)$ & $22(95.7)$ & $0.4(0.1-2.8)$ \\
\hline No & $95(11.0)$ & $766(89.0)$ & 1.0 \\
\hline \multicolumn{4}{|l|}{ Self-reported vision } \\
\hline Difficult/can’t see & $32(18.4)$ & $142(81.6)$ & $2.2(1.4-3.6)$ \\
\hline Can see & $64(9.0)$ & $646(91.0)$ & 1.0 \\
\hline \multicolumn{4}{|l|}{ Self-reported hearing } \\
\hline Difficult/can't hear & $35(18.9)$ & $150(81.1)$ & $2.4(1.6-3.8)$ \\
\hline Can hear & $61(8.7)$ & $638(91.3)$ & 1.0 \\
\hline \multicolumn{4}{|c|}{ Mobility of the upper part of body } \\
\hline Difficult & $21(24.1)$ & $66(75.9)$ & $3.1(1.8-5.3)$ \\
\hline Can move & $75(9.4)$ & $722(90.6)$ & 1.0 \\
\hline \multicolumn{4}{|c|}{ Mobility of the lower part of body } \\
\hline Difficult & $30(16.6)$ & $51(83.4)$ & $1.9(1.2-3.1)$ \\
\hline Can move & $66(9.4)$ & $637(90.6)$ & 1.0 \\
\hline
\end{tabular}

Table 4. Adjusted odds ratio for occurrence of home accidents

\begin{tabular}{lrrrr}
\hline Variable & $\begin{array}{r}\text { Beta } \\
\text { co-efficient }\end{array}$ & $\begin{array}{r}\text { Standard } \\
\text { error }\end{array}$ & Odds ratio & 95\% CI \\
\hline Hypertension & 0.68 & 0.22 & 1.96 & $1.27-3.05$ \\
Arthritis & 0.86 & 0.25 & 2.37 & $1.47-3.84$ \\
Difficulty in the mobility of upper part of the body & 0.81 & 0.29 & 2.24 & $1.27-3.96$ \\
\hline
\end{tabular}

\section{Discussion}

The incidence of home accidents which had occurred among the elderly during the past one month was $10.9 \%$. Age-specific incidence was $16.4 \%$ among elders of 75 years and above and $8.9 \%$ between $60-74$ years and sex-specific incidence for home accidents were $11.2 \%$ for females and $10.4 \%$ for males during the past one month.

A study done in a rural village of Kegalle district had found that the prevalence of home accidents among the elderly over 60 years of age was $4.9 \%$ during the previous three days (6). The incidence and prevalence 
of home accidents reported by several studies were higher than the incidence in the present study $(5,9)$. One study conducted in Turkey had found that $23.7 \%$ had home accidents within the past six months and the duration considered was six months (5). Another study found the incidence of home accidents in the elderly within the past 12 months to be $38.6 \%$ (9). In a study done in Scotland, the prevalence was $41.7 \%$ during the past 12 months (8). As shown, the duration of assessment of home accidents varies across the studies, which could be a reason for the poor comparability of results.

Out of all home accidents, falls from the same level were the commonest (41.6\%) followed by cuts and being knocked against objects. In line with our study, three studies $(5,10-11)$ have found that falls were the most common accident at home $(61.8 \%)$ followed by cuts. In contrast, another study reported that the most common injuries were bruises (39.6\%) followed by fractures and cuts among patients admitted to emergency care units (12).

Out of the 96 home accidents reported, 86 (89.6\%) had received treatment. Most of them consulted a general practitioner (32.6\%). One study reported that only $14 \%$ of those who encountered home accidents sought medical treatment (11). Three studies $(5,13-14)$ reported that approximately three fourths of the older adults who encountered home accidents were not admitted to any of the health facilities after the accident (5).

Presence of hypertension, arthritis and the mobility in the upper part of the body were found to be the significantly associated factors with the occurrence of home accidents. According to a study, out of the 27 cases of falls among persons 60 years, $37.0 \%$ had hypertension (15). This study was done in a hospital and the significance test was not applied. Arthritis, immobility and difficulty of daily living activities are inter-related. In the present study, less mobility of upper part of the body was significantly associated with the occurrence of home accidents; however, activities of daily living were not significantly associated after controlling the confounding effects. One study reported that mobility problems were documented in $22.2 \%$ of 27 elderly people who had falls (15). Another study revealed that physical disability was a risk factor for home accidents (9). The definitions were different in the two studies and therefore, a comparison could not be made.
We found that age groups were not significantly associated with the occurrence of home accidents. One study had found that the occurrence of accidents was not related to age, which was consistent with present study (9). Another study found that home accidents increased with increasing age (5). Presence of arthritis or restriction of mobility could be a confounding factor for the association between advancing age and occurrence of home accidents.

We could not find any significant association between self-reported impairment of vision or hearing and the occurrence of home accidents. In contrast, two studies revealed visual impairment (16) and hearing problems (9) as risk factors for home accidents among the elderly. However, we assessed only self-reported vision, which could have led to information bias or advancing age being a confounding factor for the association between poor vision and occurrence of accidents.

When assessing the injury incidence retrospectively in field surveys, the quality of data can be affected by recall bias. Similar surveys done in other countries have shown that recall period of one to three months is acceptable. Therefore, the risk of recall bias was less in our study considering the period of onemonth recall.

Environmental factors which include observations in the house and garden (floor, bathroom, carpets, walls, presence of hand rails, etc.) could not be assessed in this study. Further, we were not able to make new diagnoses on chronic diseases using laboratory testing and measure vision and hearing in the field due to limited resources and practical reasons. Further research is needed to determine associated factors for each type of home accidents (falls, cuts, burns, etc.) and risk factors related to the environment. Awareness programs should be conducted for the caregivers on home accidents.

\section{Public health implications}

The incidence of home accidents among the elderly was $10.9 \%$ during the past one month. Most of them were falls from same level and had led to injury to head and neck area. Most of them consulted a doctor in the private sector. Chronic conditions such as the presence of hypertension, arthritis, difficulty in the mobility of upper part of the body were the factors significantly and independently associated with the occurrence of home accidents. 


\section{Author Declarations}

Competing interests: The authors declare that they have no competing interests.

Ethical approval and consent to participate: Ethics clearance was granted by Ethics Review Committee of the Faculty of Medicine, University of Kelaniya. Informed written consent was obtained from each participant prior to data collection.

Funding: Self-funded.

Acknowledgements: We are grateful to the study participants, the data collectors for the study and Postgraduate Institute of Medicine, University of Colombo.

Author contribution: RJ participated in the design of the study, coordinated data collection, and performed the statistical analysis. CA participated in the design of the study, performed the statistical analysis, interpreted the data and drafted the first version of the manuscript. All authors read and approved the final manuscript.

\section{References}

1. Population Division. World Population Ageing 19502050. New York: Department of Economic and Social Affairs, United Nations, 2015.

Available from: http://www.un.org/esa/population/ publications/worldageing19502050/

2. De Silva WI. A population projection of Sri Lanka for the new millennium 2001-2101; trends and implications ( $1^{\text {st }}$ edition). Colombo: Institute for Health Policy, 2007.

3. Advisory Group on Prevention of Accidents in Childhood \& WHO. Accidents in childhood: facts as a basis for prevention. WHO Technical Report Series No. 118; 57: 34-35. Geneva: World Health Organization, 1957.

4. Donald IP \& Bullpit CJ. The prognosis of falls in elderly people living at home. Age and Ageing 1999; 28(2): 121-125.

5. Keskinoglu P, Picakciefe M, Bilgic N, Giray H, Karakus N, Ucku R. Home accidents in the community-dwelling elderly in Izmir, Turkey. How do prevalence and risk factors differ between high and low socio-economic districts? Journal of Aging Health 2008; 20(7): 824-836.

6. Kumarasiri, PVR. Socio-economic and behavioural risk factors of home accidents in a rural area in Sri Lanka. MD Thesis (Community medicine). Colombo: Post Graduate Institute of Medicine, 1993.

7. Lim KH, Asvindar K, Normala I, Yau WK, S Mohmad S, Lai WY, Sherina MS. Risk factors of home injury among elderly people in Malaysia. Asian Journal of Gerontology \& Geriatrics 2013; 8(1).

8. Gutman GM. Home accidents amongst elderly people: a locality study in Scotland. Journal of Social and Psycho Social Gerontology 2007; 1: 1-12.

9. Evci ED, Ergin F, Beser E. Home accidents in the elderly in Turkey. Tohoku Journal of Experimental Medicine 2006; 209: 291-301.

10. Camilloni L, Farchi S, Rossi PG, Chini F, Giorgio MD, Molino N. A case-control study on risk factors of domestic accidents in an elderly population. International Journal of Injury Control and Safety Promotion 2011; 18(4): 269-276.

11. Carter SE, Campbell EM, Sanson-Fisher RW, Gillespie WJ. Accidents in older people living at home: a community-based study assessing prevalence, type, location and injuries. Australian New Zealand Journal of Public Health. 2000; 24(6): 633-636.

12. Panatto DI, Gasparini R, Vitale A, Sasso T, Lugarini J, Cremonesi I, Sensi S, Badolati G. Survey of domestic accidents in the elderly in the Province of Genoa (Northern Italy). Journal of Preventive Medicine \& Hygiene 2009; 50(1): 53-57.

13. Downton JH, Andrews K. Prevalence, characteristics and factors associated with falls among the elderly living at home. Aging (Milano) 1991; 3(3): 219-228.

14. Graham HJ, Firth J. Home accidents in older people: role of primary health care team. British Medical Journal 1992; 305: 30-32.

15. James K, Shearer DE, Bourne JG, Morris C. Falls and fall prevention in the elderly: the Jamaican perspective. West Indian Medical Journal 2007; 56(6): 534-539.

16. Chang NT, Yang NP, Chou P. The incidence, risk factors and consequences of falling injury among the community elderly in Shihpai, Taiwan. Ageing Clinical and Experimental Research 2010; 22(1): 70-77. 